\title{
METODE PEMECAHAN EMULSI KRIM SANTAN UNTUK PRODUKSI KONSENTRAT PROTEIN BLONDO
}

\section{METHOD OF COCONUT MILK CREAM EMULSIONS BREAKING FOR BLONDO PROTEIN CONCENTRATE PRODUCTION}

\author{
Mariati Edam, Nova Kumolontang, Judith Mandei \\ Balai Riset dan Standardisasi Industri Manado \\ Jalan Diponegoro No: 21-22 Manado, telp/fax. (0431) 852395, 852396 \\ Email : edam.mariati@gmail.com
}

Diterima : 02-05-2019

Direvisi : 08-06-2019

Disetujui : 06-09-2019

\begin{abstract}
ABSTRAK
Blondo adalah protein yang terbentuk pada proses ekstraksi untuk mendapatkan minyak dengan proses basah dari krim kelapa. Blondo merupakan hasil samping dari pembuatan VCO dan minyak kelapa yang belum dimanfaatkan secara optimal. Protein blondo dapat diisolasi dengan cara mengkoagulasi protein dari denaturasi asam dan pengadukan. Penelitian ini bertujuan untuk menganalisis pengaruh metode pemecahan emulsi krim santan terhadap karakteristik kimia konsentrat protein blondo. Metode penelitian menggunakan metode eksperimental dengan rancangan percobaan yaitu menggunakan Rancangan Acak Lengkap (RAL) dengan perlakuan metode pemecahan emulsi yaitu fisik (pengadukan), kimia (penambahan asam cuka) dan fermentasi (fermentasi spontan), dilakukan sebanyak tiga kali ulangan. Parameter yang dianalisis dari konsentrat protein blondo yaitu kadar protein, lemak, air dan abu. Hasil analisis konsentrat protein blondo yaitu kadar protein (78.21-82.76\%), kadar lemak (0.75$0.85 \%)$, air (4.9-4.94\%) dan abu (2.30-2.38\%). Metode pemecahan emulsi berpengaruh terhadap kadar protein, kadar lemak, kadar abu dan tidak berpengaruh terhadap kadar air dari konsentrat protein blondo yang dihasilkan. Konsentrat protein blondo menggunakan metode fermentasi adalah yang terbaik dengan karakteristik sebagai berikut: kadar protein $82.76 \%$, lemak $0.75 \%$, air $4.93 \%$ dan abu $2.30 \%$.
\end{abstract}

Kata Kunci : blondo, pemecahan emulsi, protein konsentrat

\section{ABSTRACT}

Blondo is formed protein in the extraction process to obtain oil with wet process from coconut cream. Blondo is a by-product of VCO and coconut oil making which has not been utilized optimally. Blondo protein can be isolated by coagulating proteins from acid denaturation and stirring. This study aim to analyze the effect of the emulsion solving method on the chemical characteristics of blondo protein concentrate. The research method used an experimental method with a trial using a Complete Random Design (CRD) with emulsion breaking methods treatment of physical (stirring), chemical (addition of vinegar) and fermented (spontaneous fermented), each repeated for three times. Analyzed parameters from protein concentrate are protein, fat, water and ash content. The results of the analysis of blondo protein concentrate showed protein content of (78.21-82.76\%), fat content of (0.75-0.85\%), water of (4.9-4.94\%) and ash of (2.30-2.38\%). The method of breaking the emulsion has an effect on protein content, fat content, and ash content and does not effect the moisture content of the blondo protein concentrate produced. The best blondo protein concentrate is using fermentation method with the following characteristics: protein content $82.76 \%$, fat $0.75 \%$, water $4.93 \%$ and ash $2.30 \%$.

Keywords: blondo, emulsion breaking, protein concentrate 


\section{PENDAHULUAN}

D rotein blondo dapat diproduksi dari pemecahan santan kelapa. Santan merupakan bentuk emulsi minyak dalam air dengan protein sebagai stabilisator emulsi. Air sebagai pendispersi dan minyak sebagai fase terdispersi. Di dalam sistem emulsi minyak air, protein membungkus butir-butir minyak dengan suatu lapisan tipis sehingga butir-butir tersebut tidak dapat bergabung menjadi satu fase kontinyu. Butir-butir minyak dapat bergabung menjadi satu fase kontinyu jika sistem emulsi dipecah dengan jalan merusak protein sebagai pembungkus butir-butir minyak. Protein blondo diproduksi untuk mensubstitusi penyediaan protein kedelai yang digunakan oleh industri pangan. Aplikasi protein pada produk pangan digunakan sebagai bahan baku maupun sebagai bahan tambahan dalam pengolahan makanan olahan daging dan susu, sebagai bahan pengikat dan pengemulsi dalam produk daging, dan juga banyak digunakan sebagai bahan utama dalam pembuatan daging tiruan (Hidayat, 2009). Protein kedelai merupakan produk impor, untuk itu perlu mencari alternatif pengganti kedelai. Potensi protein nabati lokal yang perlu dijajagi pengembangannya untuk memenuhi kebutuhan industri dalam negeri diantaranya adalah blondo hasil samping pengolahan VCO dan minyak kelapa. Ketersediaan blondo tidak diragukan karena Indonesia merupakan negara produsen kelapa.

Pemecahan emulsi krim santan dapat dilakukan dengan metode fisik, kimia dan fermentasi dengan tujuan untuk mendapatkan minyak maupun blondo. Pemecahan emulsi dengan metode fisik dapat dilakukan dengan pengadukan. Pengadukan pada emulsi minyak dalam air bertujuan untuk mengganggu kestabilan emulsi agar minyak keluar. Dalam operasi pengadukan terjadi gerakan rotasi antar melekul dan netralisasi zeta potensial sehingga menurunkan viskositas larutan. Zeta potensial adalah gaya yang menjaga agar droplet-droplet emulsi tetap dalam keadaan stabil (Bregas et al., 2010). Keunggulan metode ini yaitu sederhana dan tanpa penambahan zat aditif sedangkan kelemahannya yaitu penggunaan energi listrik oleh alat pengaduk. Pemecahan emulsi metode kimia diantaranya dengan penambahan asam (asam asetat). Protein pada emulsi santan berada di atas $\mathrm{pH}$ isolistrik dan menyebabkan protein akan bermuatan negatif. Hal ini akan menimbulkan gaya tolak menolak antar partikel-partikel negatif dan mencegah terjadinya agregasi. Tetapi dengan penambahan asam akan membuat protein berada pada $\mathrm{pH}$ isolistriknya sebagai akibat kation $\left(\mathrm{H}^{+}\right)$pada gugus karboksilat dari asam akan menetralkan muatan negatif pada kation. Pada $\mathrm{pH}$ isolistrik inilah protein akan mengalami denaturasi sehingga terjadi penggabungan partikel-partikel terdispersi membentuk agregat. Hal ini akan membuat emulsi pecah sehingga minyak akan keluar (Fachry HAR dan Arta S, 2007). Cuka merupakan suatu senyawa turunan dari asam karboksilat yang mengandung gugus karbosilat, $-\mathrm{COOH}$. Nilai keasaman dari cuka yang rendah relatif stabil terhadap air dan lebih mudah mengikat senyawa lain yang bersifat basa sehingga membentuk suatu garam (Mulyaningsi S dan Fatarina E, 2004). Keunggulan metode ini yaitu asam asetat yang digunakan mudah diperoleh dan dapat diterima secara fisiologik karena merupakan bahan tambahan dalam makanan yang dikenal sebagai asam cuka (Wadiandani et al., 2010), namun kelemahannya yaitu tambahan biaya produksi untuk pembelian asam asetat. Pemecahan emulsi dengan metode fermentasi spontan terjadi karena adanya peranan mikrobia dalam krim santan. Mikrobia tersebut menghasilkan enzim protease yang menghidrolisis protein menjadi polipeptida. Pemecahan protein pada emulsi santan akan menyebabkan terjadinya pemisahan antara fase minyak dilapisan paling atas, air pada lapisan bawah dan protein pada lapisan tengah (Soeka dan Sulistyo, 2008). Mikroba yang berperan dalam fermentasi santan yaitu bakteri asam laktat. Bakteri asam laktat akan memanfaatkan oligosakarida dan protein, mengubahnya menjadi asam laktat dan metabolit-metabolit lainnya. Asam laktat yang dihasilkan dengan cara tersebut akan menurunkan nilai $\mathrm{pH}$ dari lingkungan pertumbuhannya dan menimbulkan rasa asam. BAL secara umum, mampu menginduksi proses pemisahan minyak dan air dari santan (Rahmadi et al., 2013). Keunggulan metode ini 
yaitu pengolahan yang sederhana serta penggunaan energi yang minimal sedangkan kelemahan metode ini yaitu memerlukan waktu yang lebih lama.

Berdasarkan hal tersebut di atas maka pemilihan metode didasarkan pada kemampuan memecah emulsi untuk menghasilkan blondo yang berkualitas yaitu mengandung protein tinggi untuk diolah menjadi konsetrat protein yang bernilai ekonomi sebagai bahan baku maupun bahan tambahan produk pangan. Protein blondo yang dihasilkan diolah lanjut menjadi konsentrat protein dengan cara menghilangkan fraksi non protein seperti minyak dan zat lainnya dengan cara ekstraksi. Penelitian ini bertujuan untuk menganalisis pengaruh metode pemecahan emulsi krim santan terhadap karakteristik kimia konsentrat protein blondo.

\section{METODE PENELITIAN}

\section{Waktu dan Tempat}

Penelitian ini dilaksanakan selama sepuluh bulan yaitu Bulan Februari-November 2017 di Balai Riset dan Standardisasi Industri Manado.

\section{Bahan dan Alat}

Bahan baku yang digunakan dalam penelitian ini adalah kelapa parut yang dibeli di pasar tradisional jenis kelapa dalam, asam cuka merek Dixi, heksan teknis, air. Alat-alat yang akan digunakan dalam penelitian ini adalah hand blander, kompor, wajan, oven, panci, timbangan, alat press, pH meter, blender (merek Miyako tipe: BL 151 PF/AP).

\section{Metode}

Penelitian ini menggunakan metode penelitian eksperimental. Rancangan penelitian yang dilakukan yaitu Rancangan Acak Lengkap (RAL) dengan perlakuan metode pemecahan emulsi yaitu metode fisik (pengadukan selama 15 menit), kimia (penambahan asam cuka; pH 4.5) dan fermentasi spontan (selama 24 jam). Masing-masing perlakuan dilakukan sebanyak tiga kali.

\section{Prosedur Pembuatan Konsentrat Protein Blondo}

Kelapa parut yang telah disiapkan ditambah air suhu $\pm 60^{\circ} \mathrm{C}$ untuk mengekstrak santan kelapa. Santan yang dihasilkan diamkan selama 5 jam lalu isolasi krim santan. Krim santan diperlakukan sesuai perlakuan yaitu cara fisik (pengadukan 15 menit), kimia (penambahan asam aseat $\mathrm{pH}$ 4.5) dan fermentasi (fermentasi spontan selama 24 jam). Protein blondo yang terbentuk diisolasi dari minyak dan air. Panaskan blondo pada suhu $100^{\circ} \mathrm{C}$ sampai protein menggumpal. Protein yang terbentuk diangkat, tiriskan dan dipress untuk mengeluarkan minyak. Sisa minyak protein blondo diekstrak dengan heksan, dilanjutkan dengan pengepresan dan dikeringanginkan. Sesudah itu dicuci dengan air panas $\left( \pm 85^{\circ} \mathrm{C}\right)$ kemudian disaring. Protein blondo bebas minyak dikeringkan dalam oven suhu $50^{\circ} \mathrm{C}$ selama 3 jam, kemudian dihancurkan menggunakan blender dengan kecepatan putaran 7000 rpm, diayak dengan mesh berukuran 80 lalu dikemas. Skema proses pembuatan konsentrat protein blondo dapat dilihat pada Gambar 1.

\section{Metode Analisis Data}

Data dianalisis menggunakan uji varians menggunakan minitab 14 dan dilanjutan dengan uji BNT. Parameter uji yang dilakukan yaitu kadar protein (SNI 01-2986-1992 butir 5.5 metode kjeldahl), lemak (SNI 01-2891-1992 butir 8.1 metode ekstraksi), air (SNI 01-28911992 butir 5.2 metode oven) dan abu (SNI 01-2891-1992 butir 6.1 metode pengabuan). 


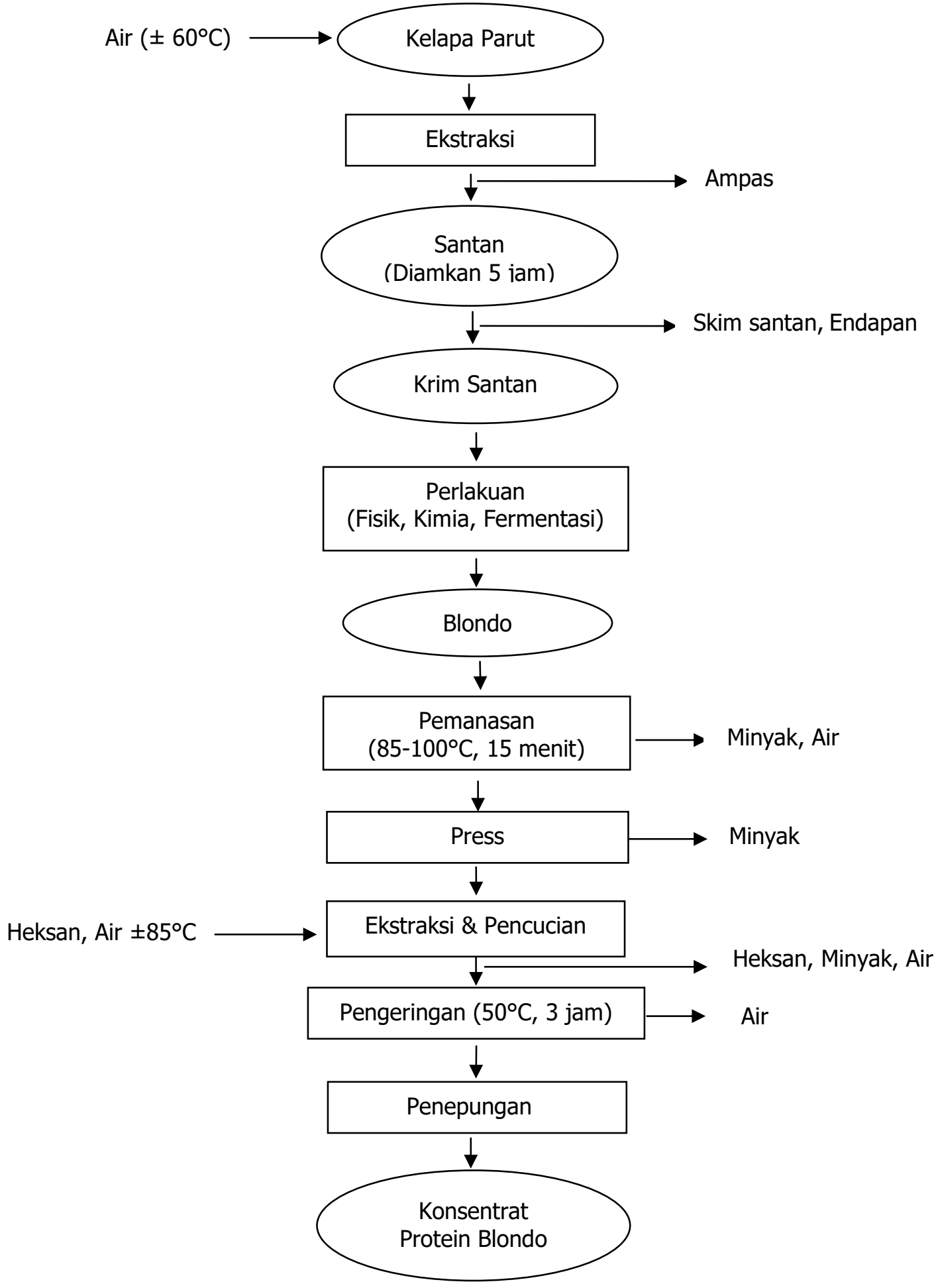

Gambar 1. Skema proses pembuatan konsentrat protein blondo 


\section{HASIL DAN PEMBAHASAN}

Sistem emulsi minyak air, protein membungkus butir-butir minyak dengan suatu lapisan tipis sehingga butir-butir minyak tersebut tidak dapat bergabung menjadi satu fase kontinyu. Protein merupakan agen pengemulsi karena memiliki gugus hidrofilik maupun hidrofobik (Mujdalipah S, 2016). Metode yang digunakan untuk merusak sistem emulsi pada penelitian ini adalah pengadukan (fisik), penambahan asam cuka (kimia) dan fermentasi (fermentasi spontan selama 24 jam). Pemecahan emulsi ini bertujuan untuk merusak dinding sel protein agar globula agar globula minyak dapat terpisah. Perlakuan ini menyebabkan terbentuk tiga lapisan yaitu lapisan protein (blondo) berada paling atas, lapisan tengah adalah minyak dan lapisan bawah adalah air. Karakteristik kimia konsentrat protein blondo yang dihasilkan dari pemecahan emulsi yang dianalisis yaitu kadar air, protein, lemak dan abu.

\section{Kadar Protein}

Data hasil analisis kadar protein dari konsentrat protein blondo dengan perlakuan metode pemecahan emulsi dapat dilihat pada Gambar 2.

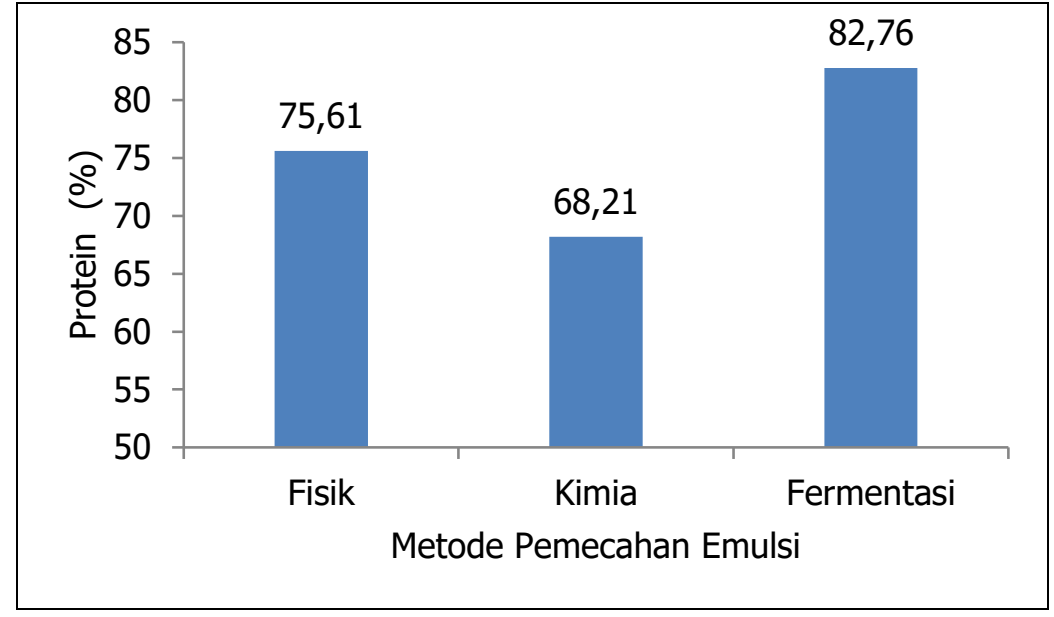

Gambar 2. Histogram pengaruh metode pemecahan emulsi terhadap kadar protein konsentrat protein blondo.

Nilai rata-rata konsentrat protein blondo dengan metode pemecahan emulsi secara fisik, kimia dan fermentasi berkisar antara 68.21-82.76\%. Semua perlakuan menghasilkan protein yang tinggi. Hasil analisis varians metode pemecahan emulsi krim santan memberi pengaruh sangat nyata terhadap kadar protein dari konsentrat protein blondo $(p<0.01)$. Hal ini menunjukkan bahwa pemecahan emulsi krim santan secara fisik, kimia dan fermentasi dapat memisahkan blondo dari minyak, air serta pengotor lainnya. Hasil uji lanjut BNT $(a=0,05)$ pengaruh cara pemecahan emulsi krim santan terhadap kadar protein menunjukkan bahwa semua perlakuan berbeda nyata. Berdasarkan hasil penelitian Karouw (2008) menunjukkan bahwa konsentrat protein kelapa mengandung kadar protein $78.28 \%$. Hal ini menunjukkan bahwa metode pemecahan emulsi krim santan secara fermentasi pada penelitian ini lebih baik karena menghasilkan konsentrat protein blondo lebih tinggi yaitu $82.76 \%$.

Pada Gambar 2 menunjukkan bahwa perlakuan pemecahan emulsi dengan metode fermentasi menghasilkan kadar protein lebih tinggi yaitu $82.76 \%$ dan terendah terdapat pada perlakuan dengan cara kimia. Hal ini dipengaruhi oleh pecahnya emulsi krim santan yang sempurna selama fermentasi 24 jam sehingga terjadi pemisahan antara protein, minyak dan air sehingga menghasilkan blondo lebih banyak. Mikroba yang berkembang selama fermentasi yaitu bakteri asam laktat. BAL ternyata dikonfirmasi keberadaannya pada blondo kelapa 
(Murtius, 2008). Menurut Redjeki (2012) proses fermentasi minyak adalah pemanfaatan substrat oleh Lactobacillus plantarum yang menghasilkan asam laktat sebagai metabolit sekunder dalam suasana anaerobik. Bakteri asam laktat akan memanfaatkan oligosakarida dan protein, mengubahnya menjadi asam laktat dan metabolit-metabolit lainnya (Rahmadi et al., 2013). Salah satu karakteristik yang paling penting dari BAL adalah kemampuannya untuk memproduksi beragam metabolit yaitu asam laktat, asam asetat, etanol, diasetil, $\mathrm{CO}_{2}$ (sebagai asam karbonat), $\mathrm{H}_{2} \mathrm{O}_{2}$, reuterin, derivat asam laktat (hidroksi asam laktat) dan peptida kecil tergantung pada tipe strain dan nutrisi, fisik, dan lingkungan pertumbuhan (Roller, 2003). Asam laktat dan asam organik seperti asam asetat yang dihasilkan oleh BAL mampu menghidrolisis protein blondo sehingga terkoagulasi. Asam laktat yang dihasilkan dengan cara tersebut akan menurunkan nilai $\mathrm{pH}$ dari lingkungan pertumbuhannya dan menimbulkan rasa asam. Hal ini menyebabkan protein-protein santan terkoagulasi akibat tercapainya titik isoelektrik menyebabkan minyak terpisah dari emulsi (Raghavendra, 2011). Pemecahan emulsi dengan pengadukan (fisik) menghasilkan konsentrat protein blondo lebih tinggi dibanding secara kimia. Hal ini menunjukkan bahwa blondo yang dihasilkan dengan cara pengadukan belum terpisah secara sempurna. Diduga karena waktu pengadukan yang kurang. Pengadukan dapat menyebabkan hilangnya stabilitas protein dalam santan. Hal ini berarti protein mengalami denaturasi sehingga kelarutannya berkurang. Lapisan molekul protein bagian dalam yang bersifat hidrofobik berbalik keluar, sedangkan bagian luar yang bersifat hidrofilik terlipat ke dalam. Hal ini meyebabkan protein mengalami koagulasi dan mengalami pengendapan, sehingga lapisan minyak dan air terpisah (Winarno, 1997). Kadar protein dari pemecahan emulsi secara kimia terlihat paling rendah (Gambar 2). Diduga karena kurang sempurnanya emulsi yang pecah mengakibatkan blondo yang terpisah dari minyak dan air menjadi kurang.

\section{Kadar Lemak}

Nilai rata-rata kadar lemak dari konsentrat protein blondo untuk semua perlakuan metode pemecahan emulsi tergolong rendah yaitu berkisar $0.75-0.85 \%$, dapat dilihat pada Gambar 3. Hasil analisis varians cara pemecahan emulsi memberi pengaruh sangat nyata terhadap kadar lemak dari konsentrat protein blondo $(p<0.01)$. Hal ini menunjukkan bahwa pemecahan emulsi krim santan secara fisik, kimia dan fermentasi dapat memisahkan minyak walaupun minyak dari blondo basah masih banyak. Hasil uji BNT $(a=0,05)$ pengaruh cara pemecahan emulsi krim santan terhadap kadar lemak menunjukkan bahwa semua perlakuan berbeda nyata.

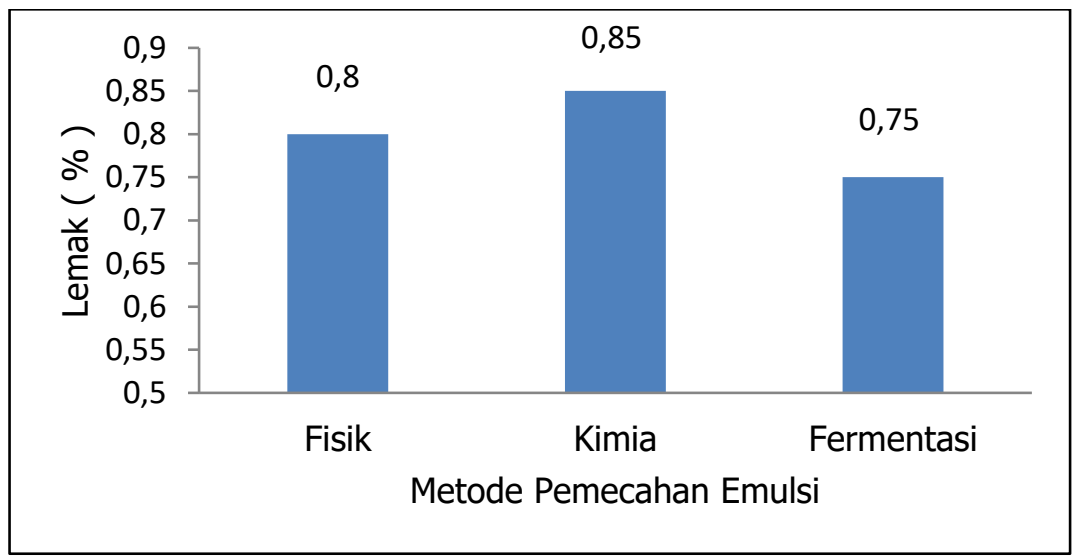

Gambar 3. Histogram pengaruh metode pemecahan emulsi terhadap kadar lemak konsentrat protein blondo 
Pada Gambar 3 menunjukkan bahwa pemecahan emulsi secara kimia menghasilkan kadar lemak konsentrat protein blondo tertinggi $(0.85 \%)$ dan kadar lemak terendah $(0.75 \%)$ secara fermentasi spontan. Tingginya kadar lemak pada perlakuan pemecahan emulsi secara kimia diduga disebabkan karena emulsi yang pecah kurang sempurna sehinggga minyak masih ada yang terperangkap dalam blondo. Penambahan asam yang berlebihan akan menyebabkan santan menjadi sangat encer dan partikel-partikel akan tersebar secara zig-zag dan saling bertumbukan yang mengakibatkan tegangan permukaan meningkat. Hal ini mengakibatkan jarak antara partikel-partikel protein makin jauh sehingga minyak yang terbentuk menjadi sedikit meskipun emulsi telah pecah dan $\mathrm{pH}$ isolistrik protein telah diturunkan sebagai akibat penetralan oleh asam (Fachry dan Arta, 2007). Sebaliknya pemecahan emulsi dengan fermentasi spontan menghasilkan kadar lemak konsentrat protein blondo lebih rendah karena emulsi santan yang pecah dari krim santan sempurna. Rendahnya kadar lemak juga dipengaruhi oleh aksi mikroba. Aksi mikroba yang dapat memecah rantai asam lemak bebas menjadi senyawa dengan berat molekul lebih rendah dan selanjutnya dioksidasi menghasilkan gas $\mathrm{CO}_{2}$ dan air $\left(\mathrm{H}_{2} \mathrm{O}\right)$. Organisme yang tumbuh dalam kondisi anaerobik pada media yang mengandung asam lemak, akan mengubah asam lemak tersebut menjadi karbon dioksida $\left(\mathrm{CO}_{2}\right)$. Namun umumnya konsentrat protein blondo yang dihasilkan melalui pemecahan emulsi baik secara fisik, kimia maupun fermentasi spontan menghasilkan konsentrat protein yang tergolong rendah. Hal ini juga dipengaruhi oleh proses ekstraksi minyak menggunakan heksana dan dilanjutkan dengan air panas.

\section{Kadar Air}

Data hasil analisis pengaruh pemecahan emulsi terhadap kadar air konsentrat protein blondo dapat dilihat pada Gambar 4. Nilai rata-rata kadar air konsentrat protein blondo pada semua perlakuan yaitu berkisar 4.90-4.94\% (Gambar 4).

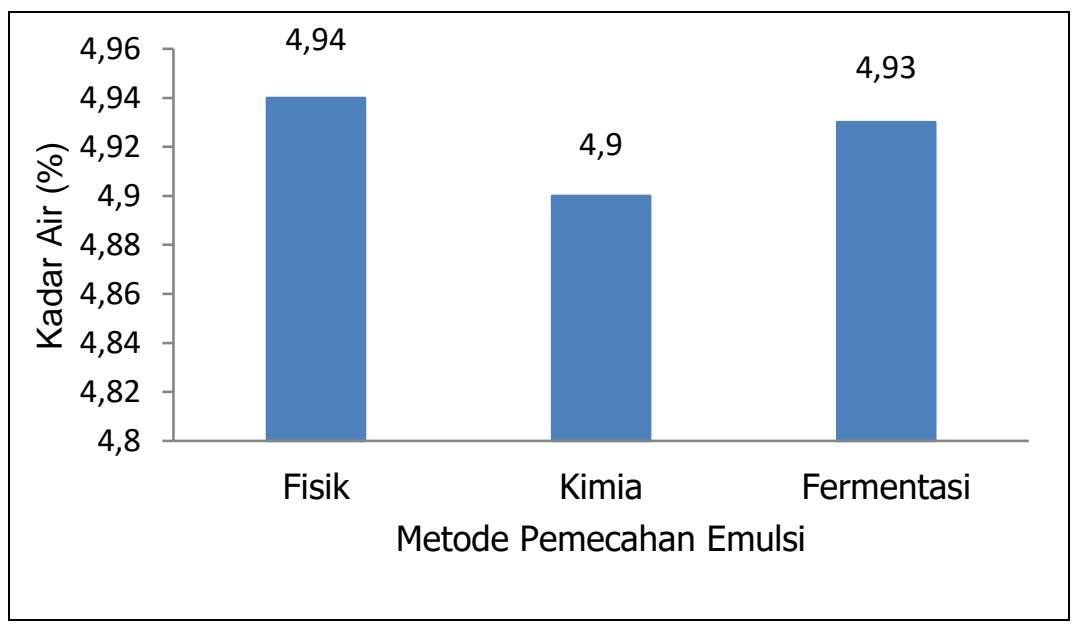

Gambar 4. Histogram pengaruh metode pemecahan emulsi terhadap kadar air konsentrat protein blondo.

Berdasarkan Gambar 4 terlihat bahwa konsentrat protein blondo yang dihasilkan memiliki kadar air yang rendah. Hal ini disebabkan karena kemampuan dari semua perlakuan dalam memecah emulsi krim kelapa menyebabkan terbentuknya air sehingga air yang terkandung dalam blondo menjadi rendah. Hasil analisis varians metode pemecahan emulsi tidak berpengaruh nyata terhadap kadar air dari konsentrat protein kelapa $(p<0.01)$. Kandungan minyak yang tinggi pada blondo mempengaruhi kapasitas penyerapan air, minyak yang terikat pada blondo kemungkinan dapat menghalangi kontak antara protein dan air karena minyak 
tersebut menyelubungi protein. Selain itu dipengaruhi faktor pemanasan yang dilakukan pada saat pemasakan blondo yang dilanjutkan dengan pengeringan dalam oven (Susanto, 2013). Pengeringan adalah suatu metode untuk mengeluarkan atau menghilangkan sebagian air dari suatu bahan dengan cara menguapkan air tersebut dengan menggunakan energi panas. Tujuan dari pengeringan adalah mengurangi kadar air bahan sampai batas dimana mikroorganisme dan kegiatan enzim yang dapat menyebabkan pembusukan akan terhenti, dengan demikian bahan yang dikeringkan dapat mempunyai waktu simpan yang lama (Riansyah dan Supriadi, 2013).

\section{Kadar Abu}

Nilai rata-rata kadar abu konsentrat protein krim blondo untuk semua perlakuan yaitu berkisar 2.30-2.38\%, dapat dilihat pada Gambar 5. Hasil analisis varians metode pemecahan emulsi memberi pengaruh nyata terhadap kadar abu dari konsentrat protein blondo $(p<0.05)$, namun berdasarkan hasil uji lanjut BNT $(a=0,05)$ menunjukkan bahwa metode fermentasi berbeda nyata dengan metode kimia, metode fisik tidak berbeda nyata dengan kedua metode lainnya.

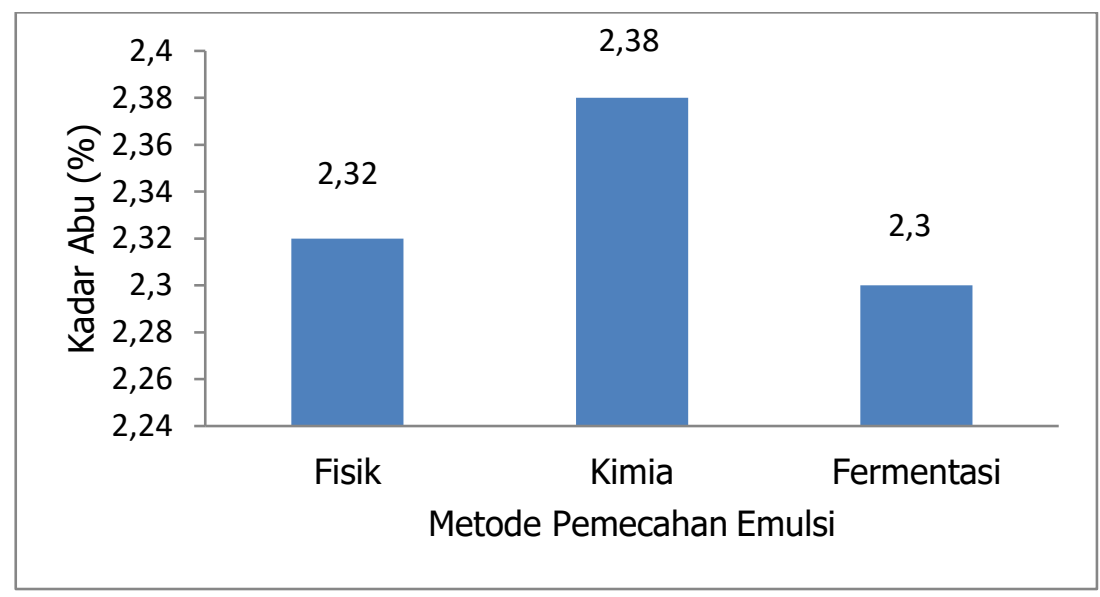

Gambar 5. Histogram pengaruh metode pemecahan emulsi terhadap kadar abu konsentrat protein blondo

Abu merupakan residu organik dari proses pembakaran atau oksidasi bahan pangan. Kadar abu dari suatu bahan menunjukan kandungan mineral yang terdapat dalam bahan tersebut, kemurnian, serta kebersihan suatu bahan yang dihasilkan (Andarwulan et al., 2011). Tingginya kadar abu pada metode kimia dipengaruhi oleh asam cuka yang ditambahkan pada krim santan. Nilai keasaman dari cuka yang rendah relatif stabil terhadap air dan lebih mudah mengikat senyawa lain yang bersifat basa sehingga membentuk suatu garam (Mulyaningsi dan Fatarina, 2004). Kandungan mineral yang terbentuk inilah yang memberi sumbangsih terhadap peningkatan kadar abu dari konsentrat protein blondo.

\section{KESIMPULAN}

Metode pemecahan emulsi krim santan secara fisik, kimia dan fermentasi berpengaruh terhadap kadar protein, lemak dan abu tetapi tidak berpengaruh terhadap kadar air dari konsentrat protein blondo yang dihasilkan.

Pemecahan emulsi krim santan secara fermentasi menghasilkan konsentrat protein blondo terbaik dengan karakteristik yaitu kadar protein $82.76 \%$, lemak $0.75 \%$, air $4.93 \%$ dan abu $2.30 \%$. 


\section{DAFTAR PUSTAKA}

Andarwulan N, Rakyat K, Kusnandar F, H. D. (2011) Analisis Pangan. Jakarta: Dian Rakyat.

Bregas ST, Sembodo B, Ardiena N, N. E. (2010) 'Pengaruh Kecepatan Putar Pengaduk Proses Pemecahan Emulsi Santan Buah Kelapa Menjadi Virgin Coconut Oil (VCO)', Ekuilibrium, 9(No.1 Bulan januari), pp. 17-22.

BSN (badan Standardisasi Indonesia) (1992) 'Cara Uji Makanan dan Minuman', Sandard Nasional Indonesia, SNI 01-2891-1992. Jakarta-Indonesia.

BSN (Badan Standardisasi Indonesia) (1992) 'Dodol', Standar Nasional Indonesia, SNI 012986-1992. Jakarta-Indonesia.

Fachry HAR, Arta S, D. S. (2007) 'Pengaruh Pemanasan danDerajat Keasaman Emulsi pada Pembuatan Minyak Kelapa', Teknik Kimia, 11(1).

Hidayat W (2009) Pengaruh Konsentrasi Gluten Tepung Terigu Terhadap Karakteristik Daging Tiruan dari Kedelai 'Glicine Max'. Bandung.

Karouw Stevi (2008) Pemanfaatan Konsentrat Protein Blondo Untuk Produk Ekstruksi. Universitas Gadjah Mada.

Mujdalipah S (2016) 'Pengaruh Ragi Tradisional Indonesia dalam Proses Fermentasi Santan terhadap Karakteristik Rendemen, Kadar Air, dan Kadar Asam Lemak Bebas Virgin Cococnut Oil (VCO)', Jurnal Fortech, 1(1), pp. 10-15.

Mulyaningsi S dan Fatarina E. (2004) 'Pembuatan Minyak Kelapa dari Santan dengan Asam Cuka Sebagai Pengendap Protein', in Prosiding Seminar Nasional Rekayasa Kimia dan Proses. Semarang: Universitas Diponegoro.

Murtius WS (2008) Pemanfaatan Blondo Sebagai Starter Dalam Pembuatan Minuman Probiotik. Universitas Andalas.

Raghavendra SN, R. (2011) 'Aqueous Extraction and Enzymatic Destabilization of Cococnut Milk Emulsions.', in, pp. 481-487.

Rahmadi A, Abdiah I, Sukarno M, P. T. (2013) 'Karakteristik Fisikokimia dan Antibakteri Virgin Coconut Oil Hasil Fermentasi Bakteri Asam Laktat', Jurnal Teknologi dan Industri Pangan ., 24(2), pp. 178-183.

Redjeki Sri (2012) Kinetika Reaksi Fermentasi VCO Secara Curah. Surabaya: UPN 'Veteran' Jawa Timur Press.

Riansyah A, Supriadi A, N. R. (2013) 'Pengaruh Perbedaan Suhu dan Waktu Pengeringan terhadap Karakteristik Ikan Asin Sepat Siam (Trichogaster pectoralis) dengan Menggunakan Oven', Fishtech, II(01. Bulan April.), pp. 53-68.

Roller, S. (2003) Natural Antimicrobials for the Minimal Processing of Foods. Ltd. Cambridge, England: Woodhead Publishing.

Soeka YS, Sulistyo J, N. E. (2008) 'Analisis Biokimia Kimia Minyak Kelapa Hasil Ekstraksi Secara Fermentasi', Jurnal Biodiversitas, 9(No.2. Bulan April), pp. 91-95.

Susanto T (2013) 'Mutu Minyak Kelapa yang Diproses Melalui Pengasaman dan Pemanasan Sesuai SNI 2902:2011', 26(No. 1), pp. 1-10.

Wadiandani T, Purwanto, Hardjono S, Bambang T, Susilowati R, D. N. (2010) 'Upaya Peningkatan Kualitas Minyak Kelapa Yang dibuat Dari Cocos nucifera L Dengan

Berbagai Metode Kimia Dan Fisik', pp. 1-6.

Winarno (1997) Kimia Pangan dan Gizi. Jakarta: Gramedia Pustaka Utama. 